\title{
Using Mobile Technology to Access Sexual and Reproductive Health Information and Services by Adolescent \& Young Persons: Findings from Nigeria
}

\author{
Eremutha Awasighe Francis ${ }^{1, *}$, Gabriel Veronica Chizoba ${ }^{1}$, Olumide Adesola ${ }^{2}$ \\ ${ }^{1}$ Women Friendly Initiative (WFI), Nigeria \\ ${ }^{2}$ Institute of Child Health, University of Ibadan/ University College Hospital, Nigeria
}

Copyright $\bigcirc 2019$ by authors, all rights reserved. Authors agree that this article remains permanently open access under the terms of the Creative Commons Attribution License 4.0 International License

\begin{abstract}
Sexual and Reproductive Health (SRH) issues are important aspects of adolescent health and development. Increasing access to newer mobile technologies such as computers and cell phones makes it possible to reach adolescents with sexual, reproductive and other health messages via these media. The study was designed to determine young people's knowledge and use of media technologies in the provision of SRH information and services. A cross-sectional study that employed a mixed methods approach was conducted. This involved both quantitative and qualitative methods. 1342 young persons were questioned: $53.1 \%$ males and $46.9 \%$ females with an overall mean age of $17.1 \pm 3.5$ years. Almost $66 \%$ of the adolescents had access to the internet and mostly at home (87.3\%). More of those in the rural (approximately $70.5 \%)$ then urban $(61.4 \%)$ had internet access and $<50 \%$ of all the young people were aware that one could obtain information on locations of youth friendly centres from electronic media. Desires to improve their knowledge on the SRH issues were some reasons mentioned by the young persons for their choice of the internet as a source of SRH information. The findings shows that it is imperative for potential providers to ensure that SRH information made available through these mobile technologies is accurate and up-to-date and that information on reliable sources of care are also provided to facilitate linkages to reliable SRH care.
\end{abstract}

Keywords Adolescent, Young People, Mobile Technology, Sexual and Reproductive Health

\section{Introduction}

Adolescence is a period of life during which the individual matures from a child to an adult ${ }^{[1]}$. Africa currently has one of the largest proportions of adolescents and young people compared to its total population ${ }^{[2]}$. The adolescent period is a time of experimentation and /or risk-taking; the individuals at this stage of life are energetic, vibrant and full of potential ${ }^{[3]}$ which if properly channelled will result in the emergence of a balanced adult. A key feature of the adolescent years is attainment of reproductive maturity. Sexual and reproductive issues are thus important aspects of adolescent development.

Globally, many people initiate sexual activity during their adolescent years ${ }^{[4]}$. Fatusi and Blum (2008) in their study on, "Predictors of early sexual initiation among a nationally representative sample of Nigerian adolescents", reported that a fifth (18\% males; $22 \%$ females) of their sample of over 2,000 never-married adolescents aged 1519 years had initiated sex. Young people all over the world are growing up in an increasingly complex environment that requires them to take tougher decisions, often without adequate preparation. Although it is generally known that the period of adolescence is a phase in life when young people are particularly vulnerable to many risks, especially in relation to their sexuality, they often lack access to adequate information, counselling and services on issues crucial to their development needs ${ }^{[5]}$.

Lack of proper information and communication are the most important factors that exacerbate and perpetuate their health problems. Adolescents are also becoming the leading subscribers of mobile phones and users of computers mainly for social networking. The explosions of electronic technologies like the availability of internet either at home or school and the wide use of mobile phones are new opportunities to provide sexual health communication to adolescents. Adolescents prefer sexual health information to be easily accessible, trustworthy, credible, confidential and non-threatening. In the light of the foregoing therefore, this study seek to illicit the viability of mobile technology as a platform of SRH information and services for young persons in Nigeria ${ }^{[6]}$. 
Early sexual initiation by adolescents is associated with a number of problems. The high rate of early sexual initiation has been linked to increased rate of unwanted pregnancies, which often leads to unsafe abortion ${ }^{[7]}$. Findings from the World Health Organization (WHO) also indicated that in 2008, there were an estimated three million unsafe abortions among $15-19$ year olds ${ }^{[8]}$. Early sexual initiation has also been linked to increased rate of school drop out for females. In 2013, almost $60 \%$ of all new HIV infections among young people aged 15-24 occurred among adolescent girls and young women ${ }^{[9]}$. Estimates suggest that the number of HIV-related deaths among adolescents is rising. There is therefore an urgent need to provide adolescents and young persons with comprehensive SRH information and services.

A noteworthy characteristic of current day youth is their proficiency in the use of the newer electronic media technologies such as computers and cell phones ${ }^{[10]}$. Improved access to these media technologies by adults and young persons alike has led to an increase in opportunities to utilize them for delivery of health services. A recent Centre for Disease Control and Prevention (CDC) whitepaper on, "Adolescents, Technology and Reducing Risk for HIV, STDs and Pregnancy", highlighted the potential to improve the sexual and reproductive health of adolescents via innovative interventions channelled through modern media technologies ${ }^{[11]}$. Nigeria is an ideal focus country for the use of new media technologies because the nation is the largest mobile market in Africa and the tenth largest in the world ${ }^{[12]}$.The International Telecoms Union (ITU) reported that in 2012, 33 percent of individuals in Nigeria were using the internet ${ }^{[13]}$. Mobile subscribers outnumber fixed line users almost 219:1, which makes the mobile device the de facto communications medium for calls, messaging, and accessing the $\mathrm{Web}^{[14]}$. Although the enormous opportunity for the use of these technologies to reach adolescents with SRH messages exists; the strategies for application are yet to be fully exploited in Nigeria.

In view of the immense, disease burden attributable to SRH problems among adolescents and young persons and the potential for reaching these young people with comprehensive interventions through readily available media technology. It is therefore, important to document their common SRH problems; their extant patterns of use of media technology; the ways by which these technologies can be further utilized to provide them with SRH information; and link them to appropriate facilities providing SRH services within their communities.

\section{Methodology}

\subsection{Sample Area and Design}

Research was conducted in six (Kaduna, Benue, Taraba,
Abia, Rivers and Oyo) states spread across all geopolitical zones and the Federal Capital Territory (FCT) of Nigeria. A mixed methods approach, utilizing quantitative and qualitative research methods was used. The quantitative study involved a questionnaire survey conducted in selected states and the Federal Capital Territory (FCT). The qualitative aspect involved the following:(i) Key informant interviews with adults who work with young persons in each state, (ii) Community mapping and Focus Group Discussions (FGD) with young persons, (III) In-depth interviews with young persons and (iv) Photovoice sessions with young persons in selected state.

\subsection{Study Participants}

Participants in this study were comprised of in and out-of-school young persons aged $10-24$ years old residing in rural and urban areas within the study areas as well as adults working with adolescents within the study sites. Where mention is made of the adults who worked with young person's/ adolescents, they are referred to as key informants or adults who work with adolescents and young persons. In each study site, the key informants were identified and purposively selected following consultations with experts who work with young people in various capacities at federal and state levels. These experts included heads of units with a focus on adolescents and young persons in the Federal Ministry of Health, members of the National Technical Working Group on Adolescent health, major NGOs, CBOs and FBOs that work with adolescents and young persons, staff of Planned Parenthood Global in the FCT as well as the adolescent health desk officers at each of the State Ministries of Health. Inclusion criteria consisted of young people aged $10-24$ years who gave their consent/ assent to participate in the study whilst exclusion criteria consist of Young people aged $10-24$ years who did not give their consent/ assent to participate in the study.

\subsection{Sample Size}

A total of 1342 and 410 (370 adolescents and 40 adults) participants were recruited across the six states and Federal Capital Territory (Abuja) to participate in the Quantitative and qualitative study respectively.

\subsection{Sampling Techniques}

A multi-stage sampling technique comprising of five stages was used for the quantitative survey.

Stage I: The Federal Capital Territory and six (Kaduna, Benue, Taraba, Oyo, Rivers and Abia) states were selected, one in each of the six geopolitical regions.

Stage II: One rural and one urban Local Government Area (LGA) were selected in each of the selected states

Stage III: This involved selection of schools for 
in-school adolescents/young persons and selection of clusters for out-of-school adolescents/ young persons. Two schools per state- one in the rural and one in the urban areas were purposively selected.

Stage IV: Selection of classes. Classes from Junior Secondary Class 1 to Senior Secondary Class 3 were selected. In schools with more than a class arm per class, one of these arms was selected by simple random sampling.

Stage V: In order to accommodate the minimum sample size, a minimum of 96 in-school adolescents - 48 from rural and 48 from urban schools were recruited. In each school, eight students (four males and four females) were recruited per class

For the Qualitative study, participants were purposively selected to ensure that these were people who could provide in-depth information as regard the study aims.

\section{Results}

\subsection{Characteristics of Respondents}

A total of 1,342 respondents participated in the quantitative study (Table. 1 ); $50.2 \%$ of them lived in urban areas within their respective states and 50.0\% were presently in school. The overall mean age of the young persons was $17.1 \pm 3.5$ years. Majority (93.4\%), were single.

\subsection{Description of Results}

Five hundred and seventy-three (42.7\%) of all the 1342 young persons reported that they needed information and/or services on SRH issues in the 12 months preceding the survey. Three hundred and sixty-two (27.0\%) of the young people required SRH information and while $376(28.0 \%)$ required SRH services.

Reports from the qualitative interviews corroborated the quantitative findings on the young persons' $\mathrm{SRH}$ information needs (Table. 2) and sources of this information (Table. 3). The SRH information needs stated during the qualitative interviews included STI/HIV prevention, correct use of condom, family planning, pregnancy prevention, contraceptives, abstinence and moral education, delaying sexual debut, menstruation, personal hygiene, and information on abortion (Fig. 1). The qualitative participants however noted that many young people found it difficult to abstain and hence needed to use condoms. Condoms were seen as an important means of protection against unwanted pregnancies and sexually transmitted infections. The young people also believed that condoms should be offered to those who find it difficult to abstain. Adolescents generally agreed that unprotected sexual intercourse could lead to unwanted pregnancies, which could disrupt the lives of adolescents, especially the females. They believed that young people need to be educated about contraceptive methods

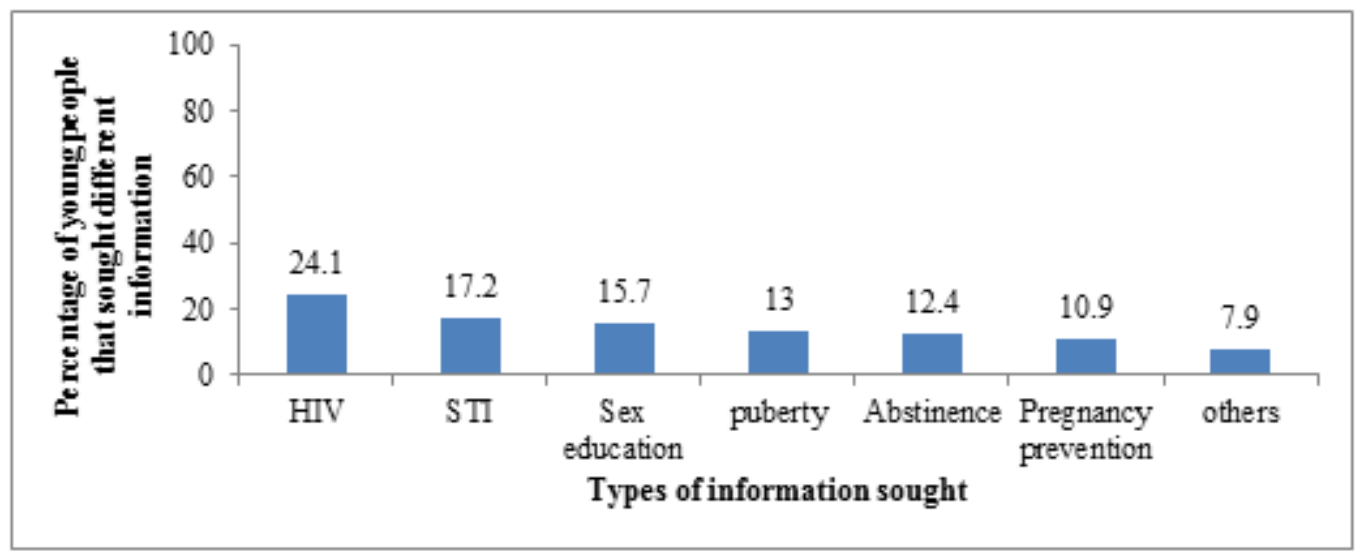

Figure 1. Types of SRH information sought for by young people in Nigeria 

and Services by Adolescent \& Young Persons: Findings from Nigeria

Table 1. Characteristics of study participants (quantitative)

\begin{tabular}{|c|c|c|c|c|c|c|c|c|c|}
\hline \multicolumn{2}{|c|}{$\begin{array}{c}\text { Socio-demographic } \\
\text { Characteristics }\end{array}$} & $\begin{array}{c}\text { South } \\
\text { West }\end{array}$ & South East & $\begin{array}{c}\text { South } \\
\text { South }\end{array}$ & $\begin{array}{c}\text { North } \\
\text { Central }\end{array}$ & North West & $\begin{array}{c}\text { North } \\
\text { East }\end{array}$ & F. C. T & Total \\
\hline Residence & Rural & $96(50.0)$ & $96(50.0)$ & $96(50.5)$ & $96(50.0)$ & $96(50.0)$ & $96(50.0)$ & $92(47.9)$ & $668(49.8)$ \\
\hline & Urban & $96(50.0)$ & $96(50.0)$ & $94(49.5)$ & $96(50.0)$ & $96(50.0)$ & $96(50.0)$ & $100(52.1)$ & $674(50.2)$ \\
\hline Gender & Male & $96(50.0)$ & $95(49.5)$ & $104(54.7$ & $117(60.9)$ & $95(49.5)$ & $112(58.3)$ & $93(48.4)$ & $712(53.1)$ \\
\hline & Female & $96(50.0)$ & $97(50.5)$ & $86(45.3)$ & $75(39.1)$ & $97(50.5)$ & $80(41.7)$ & $99(51.6)$ & $630(46.9)$ \\
\hline $\begin{array}{c}\text { Schooling } \\
\text { status }\end{array}$ & In-school & $96(50.0)$ & $96(50.0)$ & $96(50.5)$ & $96(50.0)$ & $96(50.0)$ & $96(50.0)$ & $95(49.5)$ & $671(50.0)$ \\
\hline & $\begin{array}{c}\text { Out-of-sch } \\
\text { ool }\end{array}$ & $96(50.0)$ & $96(50.0)$ & $94(49.5)$ & $96(50.0)$ & $96(50.0)$ & $96(50.0)$ & $97(50.5)$ & $671(50.0)$ \\
\hline $\begin{array}{c}\text { Age-group } \\
\text { (years) }\end{array}$ & $10-14$ & $58(30.2)$ & $58(30.2)$ & $35(18.4)$ & $21(10.9)$ & $53(28.0)$ & $30(15.6)$ & $78(40.6)$ & $333(24.9)$ \\
\hline & $15-19$ & $88(45.8)$ & $89(46.4)$ & $93(48.9)$ & $119(62.0)$ & $119(63.0)$ & $96(50.0)$ & $49(25.5)$ & $653(48.8)$ \\
\hline & $20-24$ & $46(24.0)$ & $45(23.4)$ & $62(32.6)$ & $49(27.1)$ & $17(9.0)$ & $65(34.4)$ & $65(33.9)$ & $353(26.4)$ \\
\hline $\begin{array}{c}\text { Marital } \\
\text { status }\end{array}$ & Single, & $174(90.6)$ & $185(96.4)$ & $188(98.9)$ & $172(89.6)$ & $169(88.5)$ & $184(96.3)$ & $179(93.2)$ & $1251(93.4)$ \\
\hline & Engaged & $11(5.7)$ & $6(3.1)$ & $2(1.1)$ & $3(1.6)$ & $1(0.5)$ & $3(1.6)$ & $1(0.5)$ & $27(2.0)$ \\
\hline & Married & $7(3.6)$ & $1(0.5)$ & $0(0.0)$ & $11(5.7)$ & $19(9.9)$ & $3(1.6)$ & $11(5.7)$ & $52(3.9)$ \\
\hline & $\begin{array}{c}\text { Divorced, } \\
\text { separated } \\
\text { or deserted }\end{array}$ & $0(0.0)$ & $0(0.0)$ & $0(0.0)$ & $6(3.1)$ & $1(0.5)$ & $1(0.5)$ & $1(0.5)$ & $9(0.7)$ \\
\hline Total & Widowed & $0(0.0)$ & $0(0.0)$ & $0(0.0)$ & $0(0.0)$ & $1(0.5)$ & $0(0.0)$ & $0(0.0$ & $1(0.1)$ \\
\hline
\end{tabular}

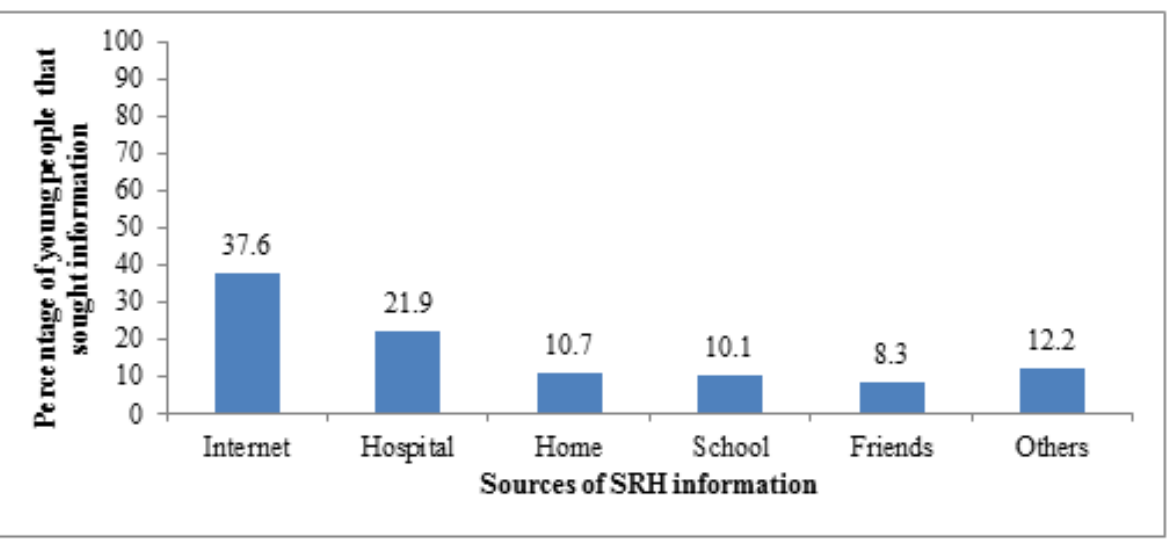

Figure 2. Sources of SRH information among young people 
Table 2. Types of information needed by adolescents in the 12 months preceding the study

\begin{tabular}{|c|c|c|c|c|c|c|c|c|}
\hline & \multicolumn{8}{|c|}{ Types of SRH information required* } \\
\hline $\begin{array}{l}\text { Selected } \\
\text { characteristics }\end{array}$ & STI & HIV & Puberty & Abstinence & $\begin{array}{l}\text { Pregnancy } \\
\text { prevention }\end{array}$ & $\begin{array}{c}\text { Sex } \\
\text { education }\end{array}$ & Others & Total \\
\hline \multicolumn{9}{|l|}{ Zone } \\
\hline FCT & $7(9.2)$ & $32(42.1)$ & $10(13.2)$ & $5(6.6)$ & $3(4.0)$ & $9(11.8)$ & $12(15.8)$ & 76 \\
\hline North west & $6(15.0)$ & $12(30.0)$ & $7(17.5)$ & $3(7.5)$ & $8(20.0)$ & $4(10.0)$ & $0(0.0)$ & 40 \\
\hline North east & $10(16.9)$ & $7(11.9)$ & $3(5.1)$ & $12(20.3)$ & $5(8.5)$ & $22(37.3)$ & $0(0.0)$ & 59 \\
\hline North central & $15(32.6)$ & $11(23.9)$ & $7(15.2)$ & $8(17.4)$ & $2(4.4)$ & $2(4.4)$ & $1(2.2)$ & 46 \\
\hline South west & $5(31.3)$ & $4(25.0)$ & $2(12.5)$ & $0(0.0)$ & $1(6.3)$ & $4(25.0)$ & $0(0.0)$ & 16 \\
\hline South east & $2(4.8)$ & $7(16.7)$ & $7(16.7)$ & $5(11.9)$ & $5(11.9)$ & $6(14.3)$ & $10(23.8)$ & 42 \\
\hline South south & $12(23.1)$ & $7(13.5)$ & $7(13.5)$ & $8(15.4)$ & $12(23.1)$ & $5(9.7)$ & $4(7.7)$ & 52 \\
\hline \multicolumn{9}{|l|}{ Residence } \\
\hline Rural & $33(18.3)$ & $37(20.6)$ & $23(12.8)$ & $18(10.0)$ & $17(9.4)$ & $37(20.6)$ & $19(10.6)$ & 180 \\
\hline Urban & $24(15.9)$ & $43(28.5)$ & $20(13.2)$ & $23(15.2)$ & $19(12.6)$ & $15(9.9)$ & $8(5.3)$ & 151 \\
\hline \multicolumn{9}{|l|}{ Gender } \\
\hline Male & $26(15.6)$ & $49(29.3)$ & $13(7.8)$ & $16(9.6)$ & $21(12.6)$ & $32(19.2)$ & $11(6.6)$ & 167 \\
\hline Female & 31(18.9) & $31(18.9)$ & $30(18.3)$ & $25(15.2)$ & $15(9.2)$ & $20(12.2)$ & $16(9.8)$ & 164 \\
\hline \multicolumn{9}{|l|}{ Age } \\
\hline $10-14$ & $6(10.2)$ & $14(23.7)$ & $14(23.7)$ & $15(25.4)$ & $3(5.1)$ & $6(10.2)$ & $3(5.1)$ & 59 \\
\hline $15-19$ & $29(18.4)$ & $31(19.6)$ & $22(13.9)$ & $20(12.7)$ & $17(10.8)$ & $31(19.6)$ & $8(5.1)$ & 158 \\
\hline $20-24$ & $22(19.3)$ & $35(30.7)$ & $7(6.1)$ & $6(5.3)$ & $16(14.0)$ & $15(13.2)$ & $16(14.0)$ & 114 \\
\hline \multicolumn{9}{|l|}{ Schooling status } \\
\hline In-school & $19(12.4)$ & $31(19.6)$ & $30(19.6)$ & $31(20.3)$ & $9(5.9)$ & $26(17.0)$ & $9(5.9)$ & 153 \\
\hline Out of school & $38(21.3)$ & $49(27.5)$ & $13(7.3)$ & $10(9.5)$ & $27(15.2)$ & $26(14.6)$ & $18(10.1)$ & 178 \\
\hline Total & $57(17.2)$ & $80(24.1)$ & $43(13.0)$ & $41(12.4)$ & $36(10.9)$ & $52(15.7)$ & $26(7.9)$ & 331 \\
\hline
\end{tabular}

*multiple response

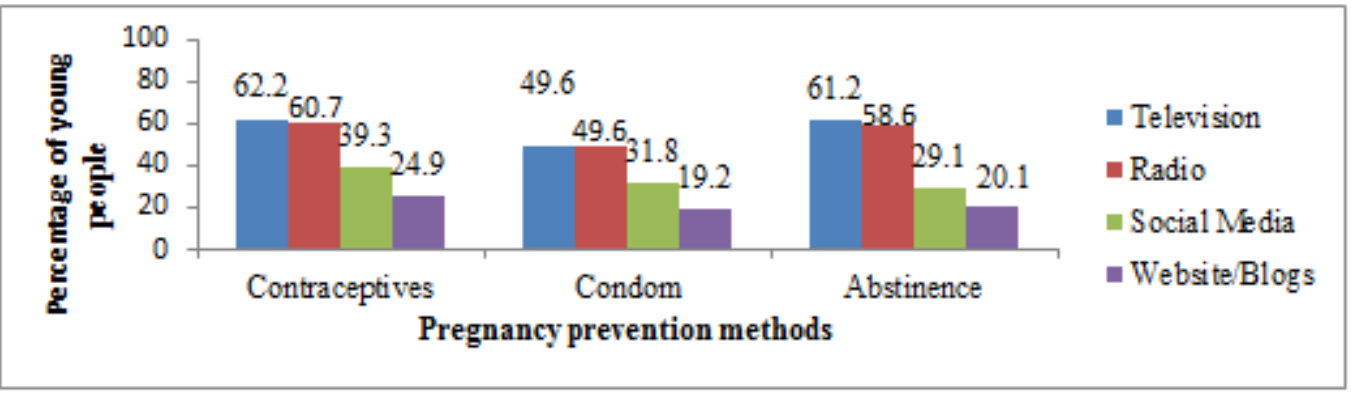

Figure 3. Knowledge of the use of media technology to access information on pregnancy prevention methods 
Table 3. Sources of information obtained by the young persons by residence and other selected characteristics

\begin{tabular}{|c|c|c|c|c|c|c|c|}
\hline \multirow{2}{*}{ Selected characteristics } & \multirow[b]{2}{*}{ Home } & \multicolumn{6}{|c|}{ Sources of SRH information obtained in the past 12 months* } \\
\hline & & School & Internet & Hospital & Friends & Others** & Total \\
\hline & $\mathrm{N}=36$ & $\mathrm{~N}=34$ & $\mathrm{~N}=127$ & $\mathrm{~N}=74$ & $\mathrm{~N}=28$ & $\mathrm{~N}=39$ & $\mathrm{~N}=338$ \\
\hline & $\mathrm{n}(\%)$ & $\mathrm{n}(\%)$ & $\mathrm{n}(\%)$ & $\mathrm{n}(\%)$ & $\mathrm{n}(\%)$ & & \\
\hline \multicolumn{8}{|l|}{ Zone } \\
\hline FCT & $15(17.9)$ & $4(4.8)$ & $21(25.0)$ & $27(32.1)$ & $8(9.5)$ & $9(10.7)$ & 84 \\
\hline North central & $5(10.9)$ & $8(17.4)$ & $9(19.6)$ & $17(37.0)$ & $2(4.4)$ & $5(10.8)$ & 46 \\
\hline North west & $2(4.7)$ & $7(16.3)$ & $13(30.2)$ & $9(20.9)$ & $1(2.3)$ & $11(25.6)$ & 43 \\
\hline North east & $4(7.3)$ & $6(10.9)$ & $18(32.7)$ & $18(32.7)$ & $8(14.5)$ & $1(1.8)$ & 55 \\
\hline South west & $0(0.0)$ & $2(15.4)$ & $6(46.2)$ & $1(7.7)$ & $1(7.7)$ & $3(23.1)$ & 13 \\
\hline South east & $1(2.0)$ & $2(4.0)$ & $35(70.0)$ & $0(0.0)$ & $6(12.0)$ & $6(12.0)$ & 50 \\
\hline South-south & $9(19.1)$ & $5(10.6)$ & $25(53.2)$ & $2(4.3)$ & $2(4.3)$ & $4(8.5)$ & 47 \\
\hline \multicolumn{8}{|l|}{ Residence } \\
\hline Rural & $23(12.3)$ & $18(9.6)$ & $58(31.0)$ & $53(28.3)$ & $14(7.5)$ & $21(11.2)$ & 187 \\
\hline Urban & $13(8.6)$ & $16(10.6)$ & $69(45.7)$ & 21(13.9) & $14(9.3)$ & $18(11.9)$ & 151 \\
\hline \multicolumn{8}{|l|}{ Gender } \\
\hline Male & $12(7.0)$ & $12(7.0)$ & $84(48.8)$ & $30(17.4)$ & $13(7.6)$ & $21(12.2)$ & 172 \\
\hline Female & $24(14.5)$ & $22(13.3)$ & $43(25.9)$ & $44(26.5)$ & $15(9.0)$ & $18(10.8)$ & 166 \\
\hline \multicolumn{8}{|l|}{ Age } \\
\hline $10-14$ & $12(18.8)$ & $7(10.9)$ & $22(34.4)$ & $4(6.2)$ & $8(12.5)$ & $11(17.2)$ & 64 \\
\hline $15-19$ & $19(12.0)$ & $25(15.8)$ & $56(35.4)$ & $28(17.7)$ & $8(5.1)$ & $22(13.9)$ & 158 \\
\hline $20-24$ & $5(4.3)$ & $2(1.7)$ & $49(42.2)$ & $42(36.2)$ & $12(10.3)$ & $6(5.2)$ & 116 \\
\hline \multicolumn{8}{|l|}{ Schooling status } \\
\hline In-school & $30(19.1)$ & $28(17.8)$ & $54(34.4)$ & $12(7.6)$ & $10(6.4)$ & $23(14.6)$ & 157 \\
\hline Out of school & $6(3.3)$ & $6(3.3)$ & $73(40.3)$ & $62(34.3)$ & $18(9.9)$ & $16(8.8)$ & 181 \\
\hline
\end{tabular}

*multiple responses; ** others include social media, mass media, books, patent medicine stores/vendors and churches.

Common primary sources of SRH information (Fig. 2) for adolescents mentioned by the qualitative study participants were religious houses, billboards and pamphlets, books, National Youth Service Corps members (NYSC), phones, laptops, internet and social network sites, school counsellors, peers, family members, relatives, mentors, youth friendly sites, youth friendly centres/ NGOs, medical centres, radio and TV/ media, tabloids, seminars/ workshops/ outreaches, and teachers.

\subsection{Knowledge of the Use of Media Technology for SRH Information and Service}

The young people's knowledge of the use of media technology for obtaining SRH information (Fig. 3) and service was assessed. This was done by enquiring if the young persons were aware that SRH information and services such as STI (including HIV) prevention, pregnancy prevention including contraceptives, STI treatment, counseling and location of Youth Friendly clinics/ service providers) could be obtained from the following media channels - television, radio, social media and websites/ blogs.

The young people provided various reasons why they searched for information on the internet (Fig. 4). Some of these reasons included: a desire to improve their knowledge on selected issues $(58.0 \%)$, the internet was a reliable source of information (11.9\%) and it was easy to access $(8.8 \%)$. Other reasons included; privacy $(6.2 \%)$, the right place $(5.7 \%)$, needed urgent help (4.1\%). Other reasons stated by young people included that they had no other alternative (no choice), services were cheap, and the perception that the source that they had accessed was the accessible place.

\subsection{Young Persons' Use of Downloaded Apps}

The young persons had applications downloaded and installed on their phones most of which were social networking sites. Other downloaded applications were games; browsers such as UCbrowser ${ }^{\circledR}$, Operamini ${ }^{\circledR}$, and Google $₫$; information applications such as dictionary, quiz apps, super sports, health app, bible, and utility apps such as scanner, flash share, drop box, calculator, etc. Social network apps (91.3\%) was the highest reported app young people had downloaded on their phones. Other apps that a few $(2.3 \%)$ of the young people downloaded were: utility apps, photoeditors, anti-virus and news apps (1.1\%). 
Figure 5. shows a distribution of the different apps young people have on their phones.

Adolescents were asked to report social network sites/ online chat apps they regularly visit/ use, (regularly visit was defined as at least twice a week). The social network site visited by the highest proportion of young persons was Facebook (82.1\%).Others included Twitter, WhatsApp,
2 go and Instagram. Facebook (41.5\%) was also listed by young persons as their favorite social network site, followed by WhatsApp (27.3\%), then 2go (25.4\%) (Fig. 6). Other sites visited by young persons include Waptrick and Wapdam: browsers such as Google, game sites, news sites such as BBC, News update, etc., porn sites and Goal.com and Nigeria Today.

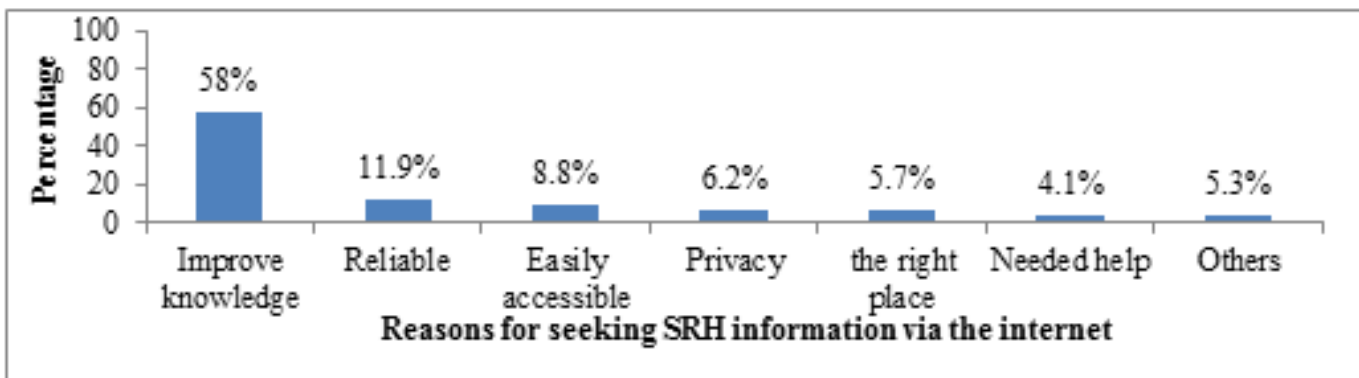

Figure 4. Reasons young people sought SRH information via the internet

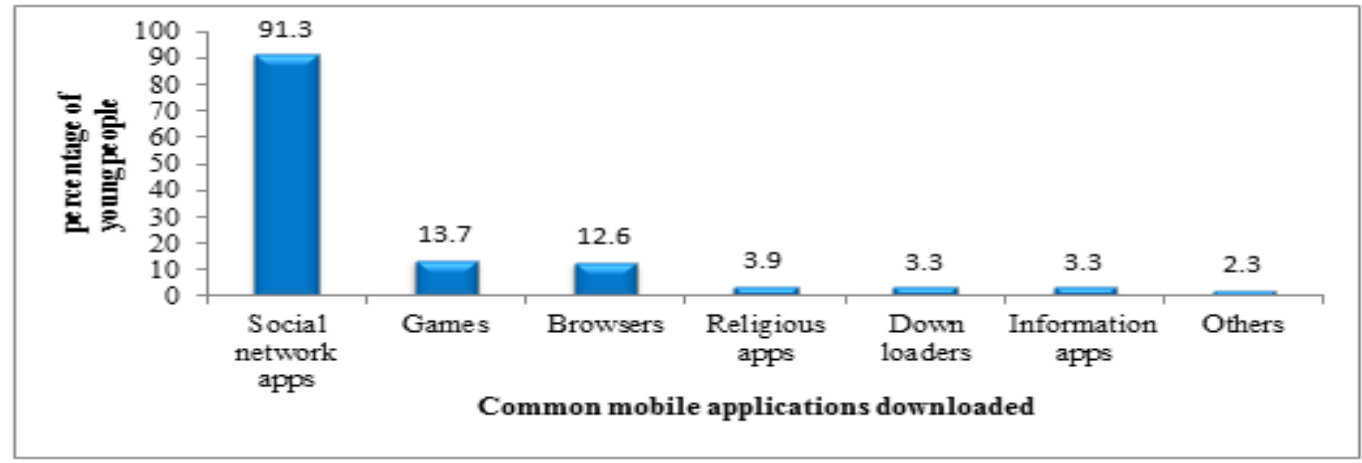

Figure 5. Common applications the young persons had downloaded on their phones

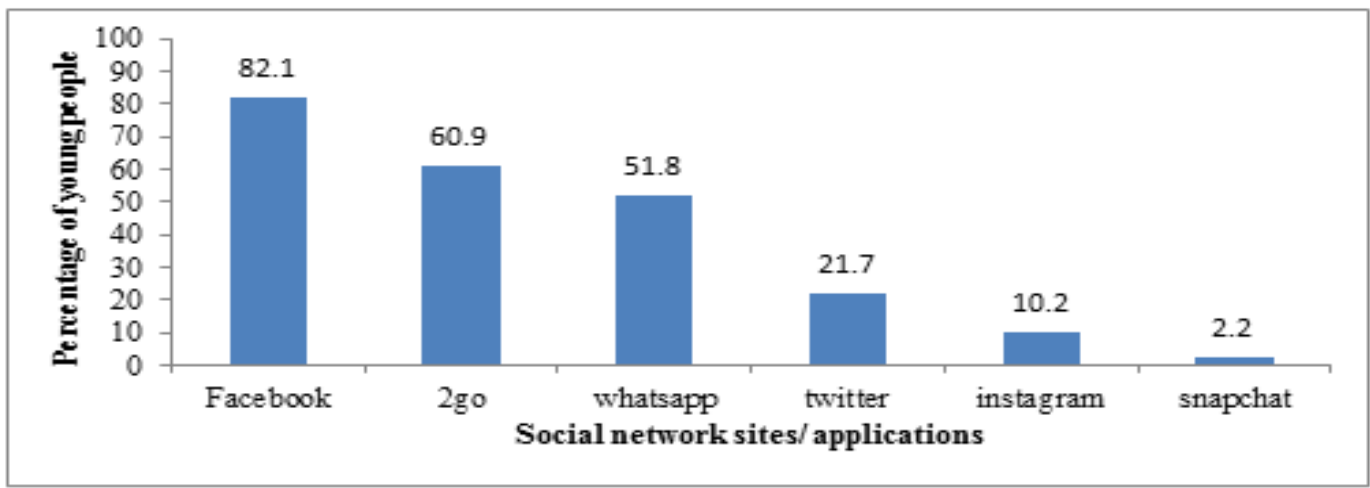

Figure 6. Regularly visited social network sites 


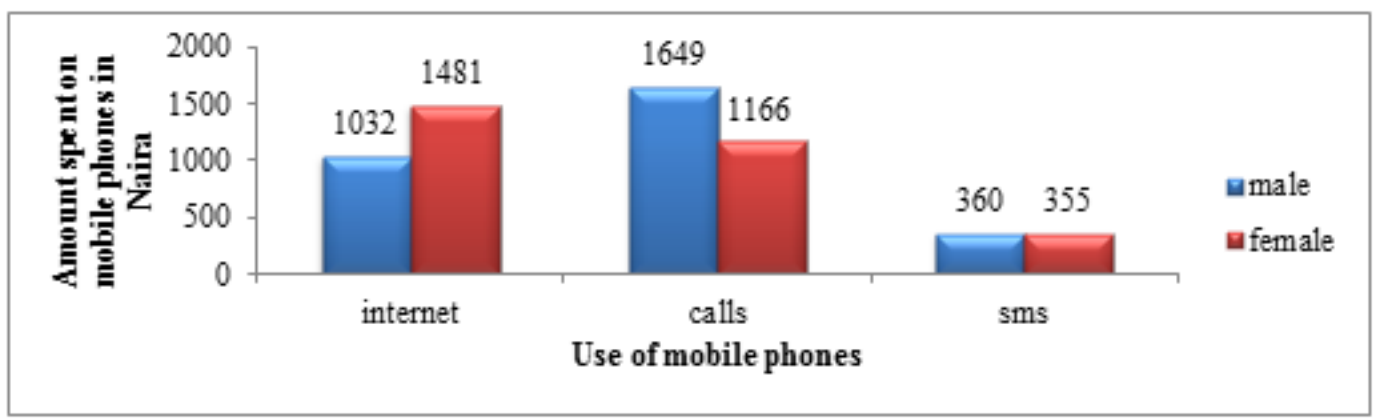

Figure 7. Mean amount spent on internet, calls and Short Message Service (SMS) by gender

\section{Discussion}

Access to mobile phones and internet was quite high with more than three quarters of the respondents reporting that they owned their own mobile phones and more than two thirds had access to the internet. This was much higher than phone ownership rates of about $40 \%$ in $2012^{[15]}$. The higher mobile phone ownership rate reported in the current study might be reflection of the increasing access to mobile phones by adolescent and young persons in Nigeria. The proportion of young persons with internet access is comparable to findings by Olumide et al who reported that about half of the in-school adolescents they interviewed had access to the internet ${ }^{[16]}$. Other studies among young people in Nigeria have also reported that many of them own mobile phones ${ }^{[17]}$.

In addition to high rates of ownership of mobile phones, the young persons were quite versatile in their use of media technologies. Many spent a considerable amount of time and money (Fig. 7) online although this varied by zone and other socio-demographic characteristics such as gender, age and schooling status. Whereas $86.7 \%$ of them were aware they could obtain SRH information through traditional electronic media (television and radio), approximately two-thirds $(66.0 \%)$ and $58.3 \%$ of the young persons were aware that they could obtain SRH information from the internet and mobile phones respectively. The young persons were also aware that various types of SRH information could be obtained from media technologies although they were more knowledgeable about the availability of SRH information on the older than newer media. The high levels of access of the young persons to mobile technologies and versatility as regards use of these media technologies creates a window of opportunity through which various Public Health interventions can be channeled. A report from a CDC whitepaper on, "Adolescents, Technology and Reducing Risk for HIV, STDs and Pregnancy",has highlighted the immense potential available to improve the sexual and reproductive health of adolescents through media technology ${ }^{[11]}$. Furthermore, many young persons believed that the internet was a reliable source of information. This preference for use of the internet might also be related to their awareness of a variety of SRH myths.
It is possible that in addition to searching for SRH information in general, they also sought for information to validate or dispel these myths since they believed the information on the internet was reliable ${ }^{[18]}$.

\section{Limitation}

A high proportion of young persons in this study obtained SRH services from hospitals $(21.9 \%)$, and this might be because the most common service obtained was HIV testing. Anecdotal reports suggest that HIV counselling and testing services are largely provided within health facilities in Nigeria although they are also provided by NGOs as part of their outreach services. It should however be noted that the young persons might not be able to differentiate between a hospital, health post or some other health facility and this might in some way account for the high proportion of those who stated that they obtained services from the hospital.

\section{Conclusions}

Young persons and higher proportions of out of school young people require SRH information and services. Many own mobile phones, have access to the internet, and are already using media technology as source of SRH information. Mobile technology is therefore a recommended option for reaching young persons in Nigeria with SRH information and referral services, given the relative ease of access it offers. In addition, mobile phones overcome the barriers associated with health facilities that are sited far from where young persons are located, as well as some issues of privacy and confidentiality.

This study demonstrates the importance for potential providers to ensure information published are: always accurate and up-to-date; covers diverse topics in order to meet the needs of various age groups of young person's; comprehensive in details; includes facts that dispel the SRH myths young persons are exposed daily; and also provide information to link the young people to facilities were they can receive definitive care and or counselling. 


\section{Acknowledgements}

The authors acknowledge Planned Parenthood Global for funding this research. Special thanks to the community stakeholders, staff and students of the schools, focal persons within the community and all young persons who participated in the survey; officers of the Non-Governmental Organizations, Faith-Based Organizations and other agencies; staff of the relevant Federal and State Ministries, Departments and Agencies, that provided relevant information and support for the conduct of this research.

\section{REFERENCES}

[1] C. McNeely, J. Blanchard. The teen years explained: A guide to healthy adolescent development. Maryland, USA: Centre for Adolescent Health, Johns Hopkins Bloomberg School of Public Health. 2009.

[2] United Nations International Children's Education Fund. Progress for Children. A report card on adolescents. (2012). Geneva, Switzerland: UNICEF.

[3] Federal Ministry of Health. National policy on the health \& development of adolescents \& young people in Nigeria. (2007). Abuja: Federal Ministry of Health.

[4] A. O. Fatusi, R . Blum. Predictors of early sexual initiation among a nationally representative sample of Nigerian adolescents. BMC Public Health, 8(1), 136. 2008.

[5] U.C. Isiugo-Abanihe, R. Olajide, E. E. Nwokocha, F. Fayehun, R. A Okunola, R. Akingbade. Adolescent Sexuality and Life Skills Education in Nigeria: To What Extent have Out-of-School Adolescents Been Reached? African Journal of Reproductive Health, 19(1): 101-111. 2015

[6] E. M. Selkie, M, Benson, M. Moreno. Adolescents' Views Regarding Uses of Social Networking Websites and Text Messaging for Adolescent Sexual Health Education. American Journal of Health Education. 42(4):205-212. 2011

[7] D. A. Grimes, J. Benson, S. Singh, M. Romero, B. Ganatra, F. E. Okonofua, I. H. Shah. Unsafe abortion: the preventable pandemic. The Lancet, 368(9550), 1908-1919.
(2006).

[8] World Health Organisation. Preventing early pregnancy and poor reproductive outcomes among adolescents in developing countries: What the evidence says. 2011. http://apps.who.int/iris/bitstream/10665/70813/1/WHO_F WC_MCA_12_02_eng.pdf

[9] Joint United Nations Programme on HIV/AIDS. The Gap Report, pp. 422. 2014. Retrieved fromhttp://www.unaids.o $\mathrm{rg} /$ sites/default/files/media_asset/UNAIDS_Gap_report_en .pdf

[10] M. A. Moreno, J. Kolb. Social networking sites and adolescent health. Pediatric Clinics of North America, 59(3), 601-612. (2012).

[11] R. Kachur, J. Mesnick, N. Liddon, C . Kapsimalis, M. Habel, C. David-Ferdon, J. Schindelar. Adolescents, Technology and Reducing Risk for HIV, STDs and Pregnancy. (2013). Atlanta, GA: Centers for Disease Control and Prevention.

[12] N. Aderibigbe. Nigeria leads internet usage in Africa. 2014 Retrieved from Ventures Africa website:http://venturesafri ca.com/nigeria-leads-internet-usage-in-africa/

[13] International Telecommunication Union. Measuring Information Society). Place des Nations, CH-1211 Geneva Switzerland. pp. 254. 2013.

[14] E. Moronfolu. The insiders guide to mobile Web marketing in Nigeria. mobiThinking. Retrieved November 12, 2015, 2015, from https://mobiforge.com/news-comment/the-insi ders-guide-to-mobile-web-and-marketing-nigeria

[15] F. Akinfaderin-Agarau, M. Chirtau, S. Ekponimo, S. Power. Opportunities and limitations for using new media and mobile phones to expand access to sexual and reproductive health information and services for adolescent girls and young women in six Nigerian states. African Journal of Reproductive Health, 16(2), 219-230. 2012.

[16] A. O. Olumide, P.Adams, O. K Amodu. Prevalence and correlates of the perpetration of cyberbullying among in-school adolescents in Oyo State, Nigeria. International Journal of Adolescent Medical Health, 10.1515. 2015

[17] M. O. N. Kunnuji Adolescence, Young Adulthood and Internet Use in Nigeria: a Review of What is Known and Unknown. International Journal of Economy, Management and Social Sciences, 3(1), 11-17. 2014.

[18] 1M. L. A. Gabarron, Elia and Rolf Wynn. "Use of social media for sexual health promotion: a scoping review" Global health action. 9: 32193, 2016 